\title{
Growth Pattern in the Juvenile Japanese Grass Snake, Rhabdophis tigrinus tigrinus, in Captivity
}

\author{
AKIRA MORI
}

\begin{abstract}
Twenty-seven newborn Japanese grass snakes were reared for two years and four months in captivity at room temperature. Nine snakes each were fed every second day (Group A), fourth day (Group B) and sixth day (Group C). By the fourth week, all snakes belonging to Group A had grown larger in both snout to vent length and body weight than those belonging to Group B, whereas Group B had exceeded Group $C$ only in body weight. On the contrary, condition index, calculated with the formula: body weight / (snout to vent length) ${ }^{3}$, was larger in Group B than in Group A after the age of one year. All snakes exhibited specific seasonal changes in growth pattern; body weight increased rapidly just before and after winter, whereas snout to vent length increased at a constant rate during these months. There was no apparent difference in seasonal changes of growth pattern among the three groups. Sexual dimorphism in tail ratio became distinct when snakes reached $290 \mathrm{~mm}$ in total length.
\end{abstract}

Studies on the growth of snakes have been made mainly in captivity by keeping animals and recording their weights and lengths monthly or quarterly (e.g., Dmi'el, 1967; Mishima et al., 1977; Acharjyo and Mishra, 1980; Kamura and Shimamura, 1980; Naulleau and Brule, 1981). Although some authors described growth patterns of snakes throughout several years, there has been no work referring to detailed annual growth pattern except Dmi'el (1967). Myer and Kowell $(1971,1973)$ reported daily body weight changes in king snakes and neonatal garter snakes, respectively. Even so, their observation periods were very short (about four months and five months, respectively). Hence, very little information is presently available regarding annual growth pattern in snakes.

Growth rate in snakes is positively related to food intake; several authors stated that the size of snakes depends upon the total food consumption from the results of observations in captivity (e.g. Ford, 1974; Barnard et al., 1979; Kamura and Shimamura, 1980). Very few authors, however, have analyzed the Accepted 3, Jun. 1987 relationship between the availability of food and the growth of snakes. Only Myer and Kowell (1973) reported the influence of food availability on the growth of neonatal garter snakes for a 13-week period.

The present study was conducted to clarify the influence of food intake on the growth of juvenile snakes, as well as to investigate their annual growth pattern. I also report on the sexual dimorphism in tail ratio observed in the process of growth.

\section{Materials AND Methods}

Twenty-seven Japanese grass snakes, Rhabdophis tigrinus tigrinus, were used. Their mother snake was captured on Yakushima Island, and laid 27 eggs on 6 July 1983 in captivity. They hatched from 12 to 15 August, 1983. Each hatchling was kept in a clear plastic cage $(135 \times 190 \times 60 \mathrm{~mm})$ at room temperature, which varied $22-37^{\circ} \mathrm{C}$ during the summer and $3-13^{\circ} \mathrm{C}$ during the winter. Snakes were moved to larger cages $(320 \times 230 \times 170 \mathrm{~mm})$ on 1 September, 1984, when they had grown much larger. Paper was spread on the floor of each 
aquarium. A small petri dish filled with water was in each cage at all times.

The body weight (BW, in g) and snout to vent and tail lengths (SVL and $\mathrm{TL}$, in $\mathrm{mm}$ ) of the snakes were measured every week throughout the observation period, from 8 September 1983 to the end of December 1985. Nutritional condition was expressed by a condition index, $\mathrm{CI}=$ $\mathrm{BW} / \mathrm{SVL}^{3}$, following Jørgensen (1986).

These hatchlings were divided equally into 3 groups - A, B, and C. They were fed one or two small fish of approximately the same weight every second day (Group A), fourth day (Group B), or sixth day (Group C), respectively. I offered one small fish from September 1983 to July 1984, and two small fish from August 1984 to December 1985. Goldfish or bitterlings were mainly given as prey, but occasionally minnows or bluegills were also offered. The average weight of one fish was $1.1 \mathrm{~g}$ during the observation period except in September and October 1983, when the average was $0.5 \mathrm{~g}$. The fish were presented in the petri dish with water. I checked each cage 24 hours after the prey were provided to determine if it had been eaten. When a snake had eaten the fish I recorded "accepted". When an animal had not eaten I removed the prey and recorded "rejected". I continued to provide food until all individuals refused to eat in winter. In spring I started to feed them from the middle of March.

Analysis of covariance and Student's t-test were used for statistical comparisons of regression lines in slopes and least squares means, respectively, using a GLM program (Specter et al., 1985). Mann-Whitney's U-test was used for statistical comparisons of measurements. The level of significance was $P=0.05$ in all cases.

\section{RESULTS}

Growth.-There were no sexual differences either in SLV or BW within each group throughout the observation period. Total length (TTL) of the snakes, measured two weeks after hatching, and their sexes are presented in Table 1. Figs. 1 and 2 show the growth rates of SVL and $\mathrm{BW}$ in each group, respectively. The average SVL in Group A was significantly larger than those of Groups B and C after

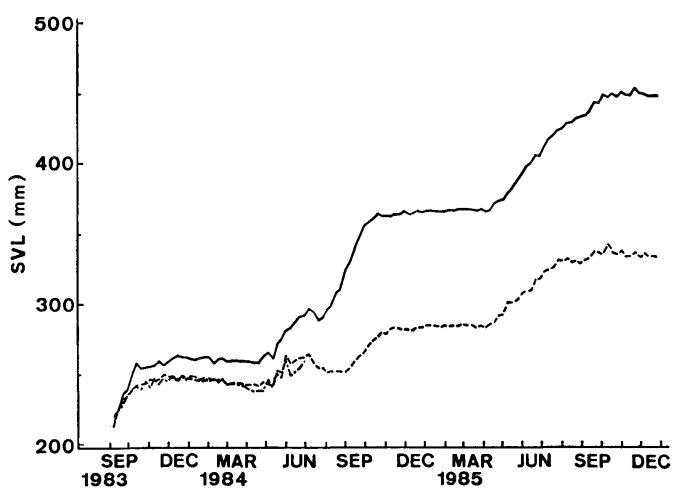

FIG. 1. Growth of SVL in Rhabdophis tigrinus tigrinus reared under various feeding regimes. Solid line: fed every second day (Group A); dashed line: fed every fourth day (Group B); dashed and dotted line: fed every sixth day (Group C).

TAABLE 1. Total lengths (TTL, in $\mathrm{mm}$ ) of juvenile Rhabdophis t. tigrinus measured two weeks after hatching and their sexes.

\begin{tabular}{cccccccccccc}
\hline Group & No. & TTL & Sex & Group & No. & TTL & Sex & Group & No. & TTL & Sex \\
\hline A & A8-1 & 250 & F & B & A8-10 & 250 & M & C & A8-19 & 260 & M \\
A & A8-2 & 260 & F & B & A8-11 & 250 & F & C & A8-20 & 270 & F \\
A & A8-3 & 270 & F & B & A8-12 & 270 & M & C & A8-21 & 270 & M \\
A & A8-4 & 270 & F & B & A8-13 & 250 & M & C & A8-22 & 250 & M \\
A & A8-5 & 270 & F & B & A8-14 & 260 & M & C & A8-23 & 250 & F \\
A & A8-6 & 270 & F & B & A8-15 & 290 & F & C & A8-24 & 260 & M \\
A & A8-7 & 250 & M & B & A8-16 & 280 & M & C & A8-25 & 260 & F \\
A & A8-8 & 260 & F & B & A8-17 & 260 & M & C & A8-26 & 270 & F \\
A & A8-9 & 260 & F & B & A8-18 & 270 & M & C & A8-27 & 250 & M \\
\hline
\end{tabular}




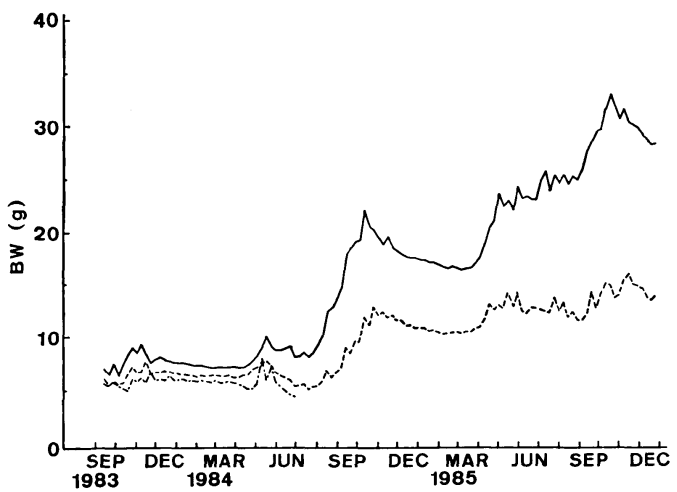

FIG. 2. Growth of BW in Rhabdophis t. tigrinus. Notations as in Fig. 1.

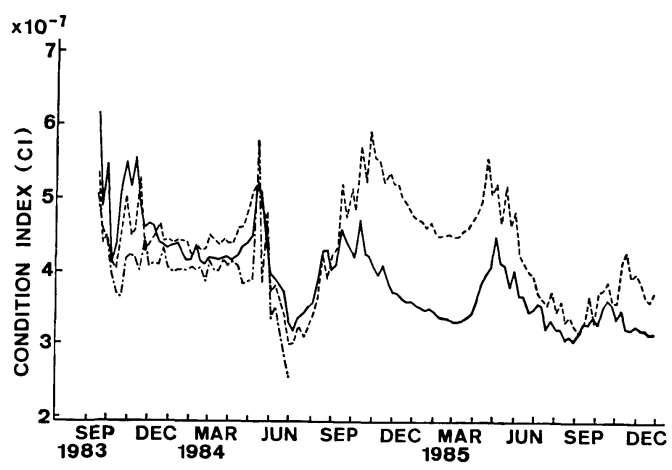

FIG. 3. Changes of condition index in Rhabdophis t. tigrinus. Notations as in Fig. 1.

the age of three months. On the other hand, SVL in Group B did not show any significant difference from that in Group $\mathrm{C}$ throughout the observation period. As to BW, there were significant differences among the three groups after the age of three months. Differences in SVL and BW between Groups A and B increased after April in 1984.

Changes in CI throughout the observation period are shown in Fig. 3. From the time of hatching to September 1984, there were no significant differences in values of this index among the three groups. Thereafter, the CI of Group B grew significantly larger than that of Group A. This result indicates that the CI of snakes fed every fourth day was larger than that of snakes fed every second day. The CI in Group A, showing seasonal fluctuation, decreased through-

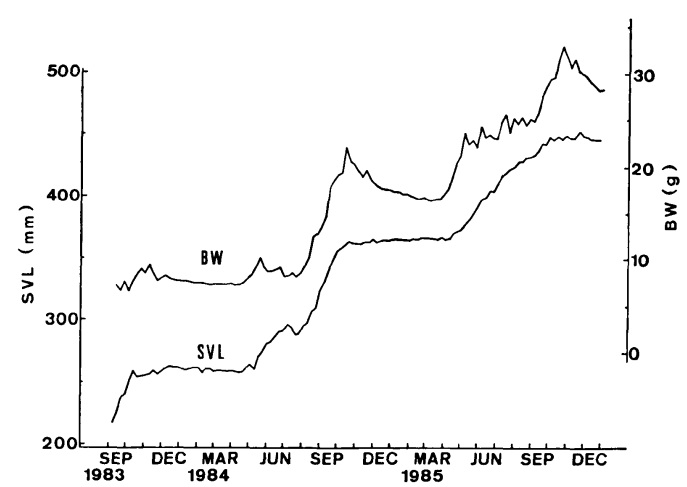

FIG. 4. Growth of SVL and BW in Group A.

out the observation period. On the other hand, in Group B, CI increased during the first year and a half, and then decreased, showing a similar seasonal fluctuation. As stated above, there was difference in the pattern of $\mathrm{CI}$ change between Group A and B.

Seasonal Changes in Growth Pattern.Fig. 4 shows the growth curves of average SVL and BW in Group A. From October to November, 1983, growth rate in SVL decreased slowly, whereas that in BW increased rapidly. The latter rate indicated remarkable increase from April to May, 1984, when the snakes resumed eating. Increase of growth rate in SVL appeared approximately two to three weeks later. Both of these rates declined in June and July 1984. From August, I started offering two fish to each snake, which resulted in the rapid increase of the rates in that month. In October 1984, growth rate in SVL decreased, whereas that in BW continued to increase. In 1985, the snakes showed seasonal changes in growth pattern similar to those of the previous year, i.e., rapid increase of $\mathrm{BW}$ prior to increase of SVL in spring, and rapid increase of BW during reduction of growth rate of SVL in autumn.

Group B also exhibited similar changes; BW increased rapidly in April and in November, whereas SVL increased at a constant rate during the entire period. 
These results indicate that food intake did not affect growth pattern either in SVL or in BW.

Winter Body Weight Loss.-The snakes exhibited rapid body weight loss during the first two weeks after they started refusing prey. The BW of each snake two weeks after it refused food, avoiding the two-week period of rapid weight loss, was regarded as the BW just before winter. Winter body weight loss was calculated as follows;

$$
\text { (BW1-BW2)/BW1 }
$$

where $\mathrm{BW} 1$ represents $\mathrm{BW}$ just before winter and BW2 represents BW just before the snake resumed eating in spring. Average winter body weight loss in Groups $\mathrm{A}, \mathrm{B}$, and $\mathrm{C}$ were $12.5 \%(\mathrm{~N}=9)$, $10.0 \%(\mathrm{~N}=8)$, and $10.4 \%(\mathrm{~N}=3)$, respectively in the first winter. In the second winter, those of Groups A and B were 9.3 $\%(\mathrm{~N}=8)$ and $7.6 \%(\mathrm{~N}=3)$, respectively. There were no significant differences in winter body weight loss either among groups or between ages. These results indicate that neither differences in food intake nor in age affected the winter body weight loss, at least in the first two years after hatching.

Mortality.-Mortality of snakes during the observation period was $1 / 9$ in Group A, 6/9 in Group B, and 9/9 in Group C. These figures appear to indicate that low food intake resulted in higher mortality in the snakes. A total of 16 snakes out of 27 died, and of these, 15 animals died within one year after hatching. In particular, all snakes in Group C, fed every sixth day, died within the first ten months (Table 2).

Feeding Period and Feeding Rates.Fig. 5 shows the feeding period of each individual. The snakes in Group C continued to eat significantly later when compared with those belonging to Groups A and B. The snakes in Group B continued to eat later than those in Group A in the first winter. In 1984, however, there was no significant difference between Groups A and B in the date the snakes refused to eat. As for the date of resuming the food intake, there was no significant difference among the three groups. However, the snakes in Group B started to eat earlier in 1985, and continued to eat later than Group A, which resulted in a longer feeding period of the former.

Feeding rates in Groups $\mathrm{A}$ and $\mathrm{B}$ were low when the snakes started to eat in spring, and increased from March to May (Fig. 6). From June to September or October, feeding rates were very high (more than $87.8 \%$ ) in each group, and decreased thereafter. These results indicate that snakes in each group ate almost all food offered except for seasons just after and just before their feeding periods.

Sexual Dimorphism in Tail Ratio.Fig. 7 shows the relation between the total and the tail lengths of the snakes. The regression lines for males and females were significantly different in both slope and least squares means. There was no significant sexual difference in the tail ratio, when animals were smaller than

TABLE 2. The dates of death in young Rhabdophis t. tigrinus.

\begin{tabular}{ccrlllllll}
\hline Group & No. & \multicolumn{3}{c}{ Date of death } & \multicolumn{2}{c}{ Group } & \multicolumn{2}{c}{ No. } & \multicolumn{2}{c}{ Date of death } \\
\hline A & A8- & 11 & MAY & 1984 & C & A8-20 & 23 & NOV. & 1983 \\
B & A8-11 & 30 & AUG. & 1984 & C & A8-21 & 30 & APR. & 1984 \\
B & A8-12 & 6 & AUG. & 1984 & C & A8-22 & 5 & JUL. & 1984 \\
B & A8-13 & 2 & MAY & 1984 & C & A8-23 & 26 & MAR. & 1984 \\
B & A8-14 & 9 & OCT. & 1983 & C & A8-24 & 1 & MAR. & 1984 \\
B & A8-15 & 9 & AUG. & 1984 & C & A8-25 & 5 & JAN. & 1984 \\
B & A8-16 & 26 & JUL. & 1984 & C & A8-26 & 5 & MAR. & 1984 \\
C & A8-19 & 3 & MAY & 1984 & C & A8-27 & 22 & OCT. & 1983 \\
\hline
\end{tabular}




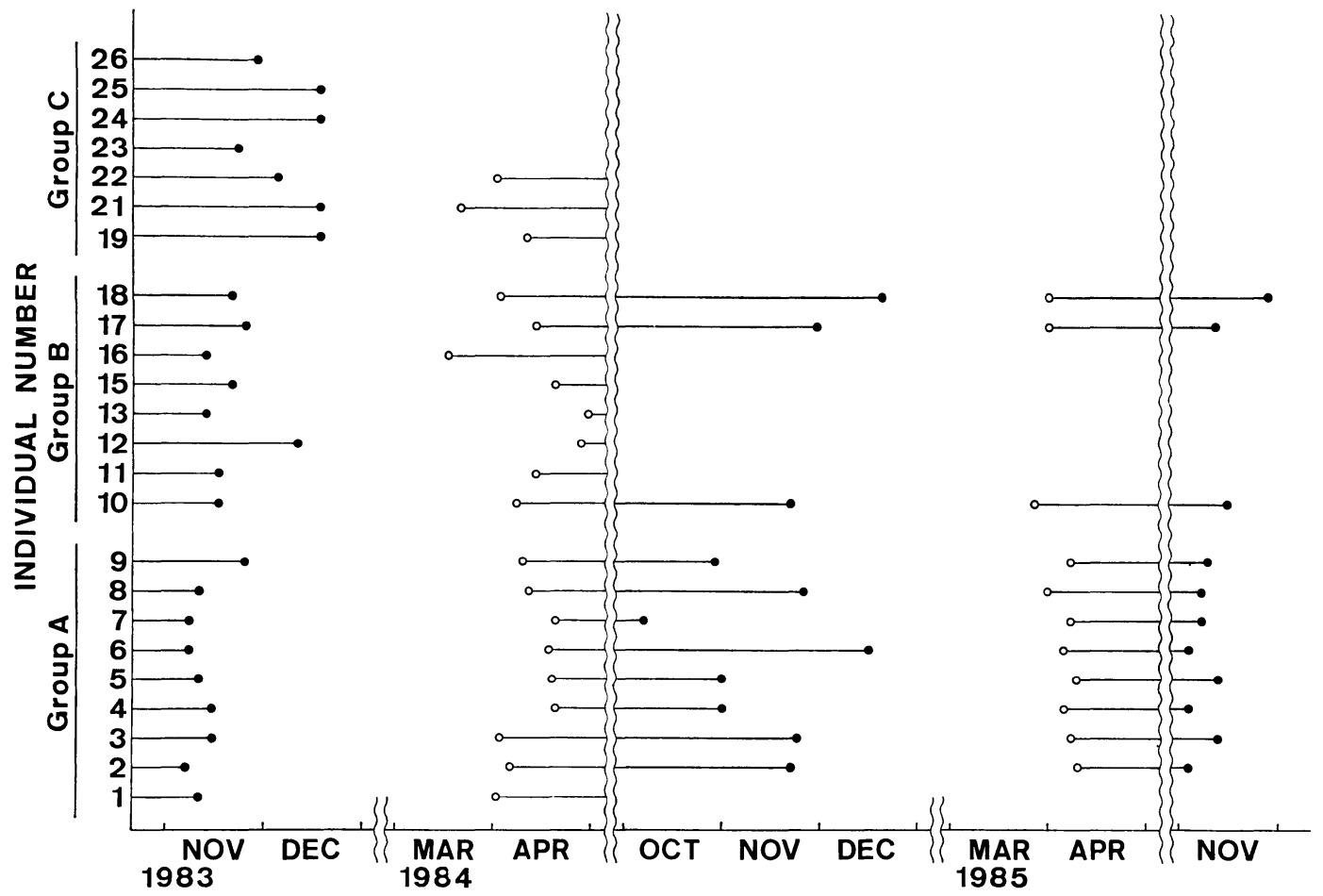

FIG. 5. Voluntary feeding periods of Rhabdophis t. tigrinus. Solid circle: the date when a snake stopped eating; open circle: the date when a snake resumed eating.

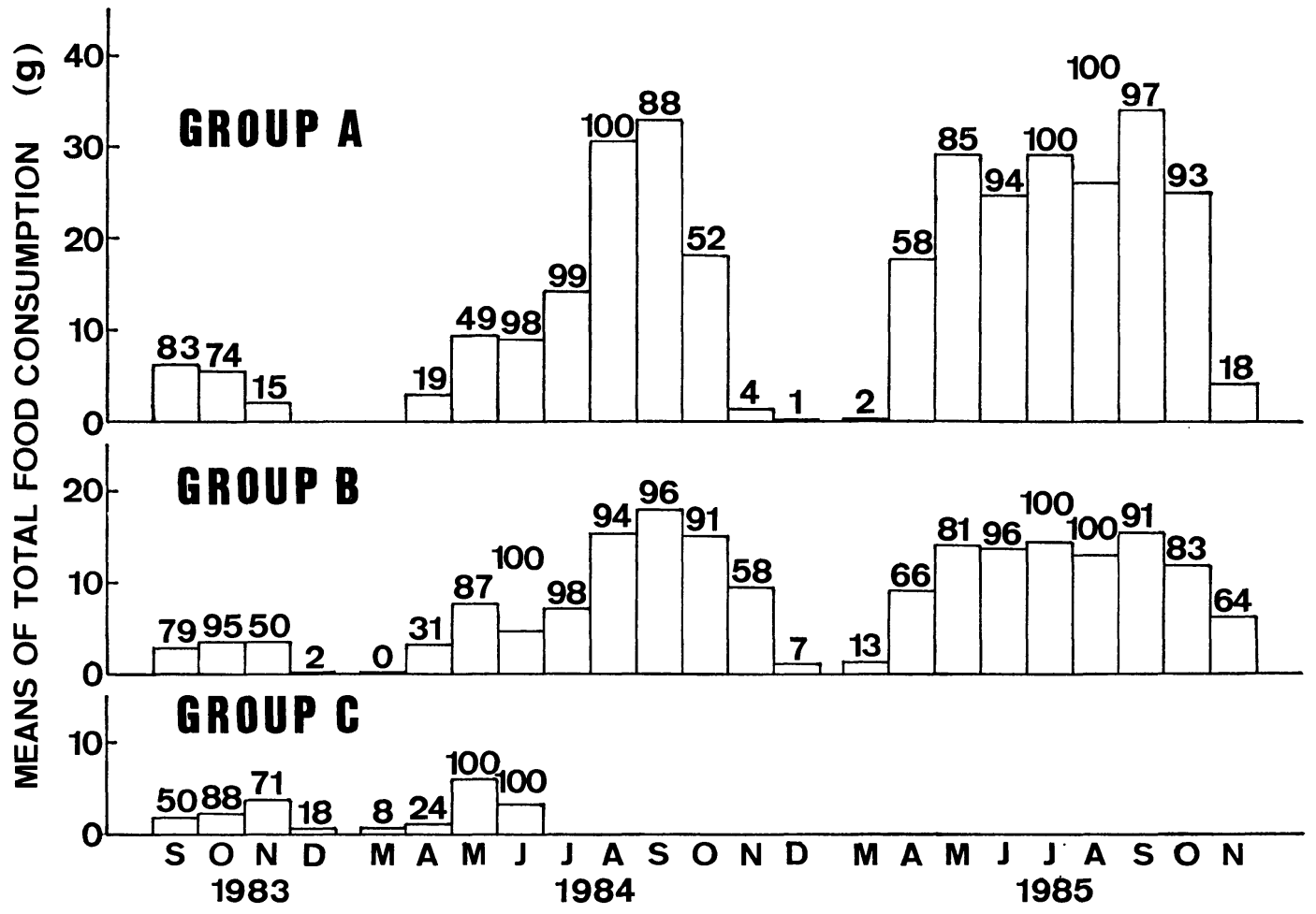

FIG. 6. Monthly feeding rates and monthly total food consumption in each group. Histograms and the numbers indicate total food consumption (in g) and feeding rates (in per cent), respectively. 


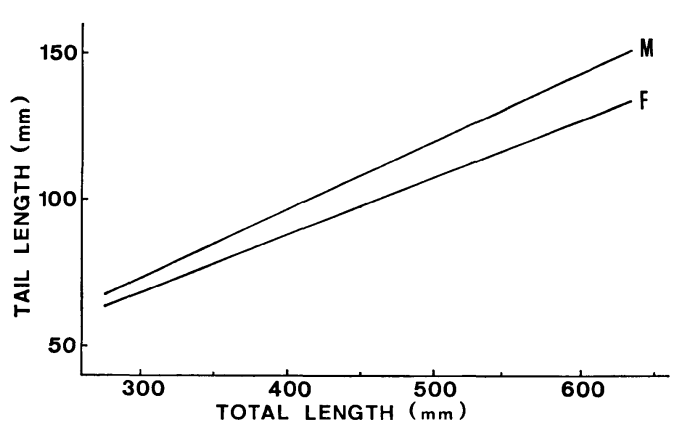

FIG. 7. Relationship between the total and the tail lengths in Rhabdophis $t$. tigrinus. Regression equations for females and males were calculated as $y=0.195 x+1.03$ and $y=0.232 x+3.99$ respectively. Regression lines for males and females differ significantly both in slopes and least squares means.

$290 \mathrm{~mm}$ in total length. The tail ratio of males was significantly larger than that of females when their total length exceeded $290 \mathrm{~mm}$. This difference became more distinct with the growth of the animals. There were no significant differences in tail ratio among the groups either in males or in females. Therefore, sexual dimorphism in tail ratio seems not to be influenced by food intake.

\section{Discussion}

Fukada (1972) reported that mortality of Rhabdophis tigrinus tigrinus in nature was very high during the first year after hatching. In the present study, 15 snakes died within one year after hatching, but only one in the second year. Nine individuals out of the 16 snakes that died belonged to Group C, six to Group B, and one to Group A. This high mortality in Group C, which fed every sixth day, suggests that food intake greatly affected the mortality during the first year after hatching.

Higher growth rates of SVL and BW in Group A than in Group B indicate that growth rates of the snakes greatly depend upon the food intake. These results coincide with those reported by Myer and Kowell (1973), who observed the growth of neonatal garter snakes (Thamnophis sirtalis). On the other hand, significant differences appeared only in BW between Groups B and C; there was no recognizable effect of food supply on SVL. Kamura (1975) stated that, in neonatal Trimeresurus flavoviridis, feeding rate affected growth of body weight rather than of total length. Moriya and Higashizono (1986) found that, in captive mamushi (Agkistrodon blomhoffii blomhoffii), the correlation between the total food consumption (total FC) and the increase of body weight was higher than the correlation between the total FC and the increase of total length. From the present study, it appears that food intake affects the growth in body weight more rapidly than in body length.

The changes in CI showed no such positive correlation with the frequency of food intake as in SVL and BW, except in the first few months after hatching. On the contrary, the CI in Group B, which received about half the amount of food of Group $\mathrm{A}$ in a given period exceeded that in the latter in the beginning of the second year. Kamura and Shimamura (1980) applied this index to young crotaline snakes (Trimeresurus flavoviridis), and found that the CI of the snakes was largest at hatching and decreased during the first two years. In the young Rhabdophis t. tigrinus, a similar pattern was seen only in Group A; in Group B, the CI was largest just before the second winter. The larger CI in Group B than in Group $A$ after the age of one year appears due to the differences in the pattern of changes in CI. This result also seems to support the idea that food intake first influences the growth of body weight and subsequently that of length. Therefore, caution is needed when using CI to compare the growth of snakes, and in particular, this index seems to be inadequate to compare the nutritional condition among snakes belonging to different size groups.

Fukada (1959) studied the growth of wild Rhabdophis t. tigrinus, and reported that the mean total length was $357 \mathrm{~mm}$ 
just before the first winter, $705 \mathrm{~mm}$ just before the second winter, and $822 \mathrm{~mm}$ just before the third winter (males and females combined). In the present study, the average total length of Group A was $336 \mathrm{~mm}$ just before the first winter, 467 $\mathrm{mm}$ just before the second winter, and $572 \mathrm{~mm}$ just before the third winter. From these figures, it is obvious that snakes were larger in nature than in captivity at least to the third year after hatching. There are several possible explanations for this difference. First, it is probable that food supply for the snakes in the present study was less than that for animals examined by Fukada (1959), which resulted in the above difference. This postulation seems to be supported by the fact that growth rates of SVL and BW of captive snakes decreased in June and July, 1984, and that feeding rates in Group A, which had highest food intake, were almost $100 \%$ in summer. On the other hand, some fish including goldfish contain thiaminase, which causes thiamine deficiency resulting in emaciation, secondary infections, incoordination and anorexia (Cooper and Jackson, 1981; Fowler, 1978; Marcus, 1981). In the present experiment, the snakes were fed an all-fish diet, and so, it is certain that the growth of the snakes was influenced by thiaminase. Other environmental factors, (such as temperature, size of cage, etc.) may have affected the growth of the captive animals as pointed out by Fukada (1972). Kamura and Shimamura (1980) tried to estimate the age of the snakes in nature on the basis of the growth data of snakes in captivity. However, Barnard et al. (1977) reported that the size of corn snakes depends more on food consumption than on the age. The present results coincide with Barnard's observations. That is, the mean total length of Group A (fed every second day) just before the second winter was larger than that of Group B (fed every fourth day) just before the third winter. Thus, much cau- tion is needed when estimating the age of wild snakes on the basis of the growth data of captive snakes.

Winter body weight loss of Rhabdophis t. tigrinus in the present study was $10.3 \%$ on the average. This value is much larger than that of wild snakes, $5.6 \%$ on the average (Fukada, 1959). Several authors reported that body weight loss during hibernation in juvenile rattlesnakes was larger than in adults (Klauber, 1937; Hirth, 1966). On the other hand, it is assumed that the large rate of body weight loss in this study is due to the differences in the temperature and/or humidity between captive and natural environment: in this study, winter room temperatures, $3-13^{\circ} \mathrm{C}$, were higher than the temperatures in natural hibernacula (ground temperature $6-6.7^{\circ} \mathrm{C}$, Fukada 1967; ambient temperature $1-4^{\circ} \mathrm{C}$, Goris 1971$)$.

During the active season, there was a characteristic growth pattern in SVL and BW as follows. In April growth rate of BW increased rapidly and that of SVL increased a few weeks later. From May to October, the latter rate was nearly constant, whereas the former decreased. In November, the growth rate of BW increased again rapidly with a decrease in the growth rate of SVL. Some authors have reported similar annual growth patterns in body weight. Takenaka (1980) reported that wild yearlings of the Japanese grass lizard Takydromus tachydromoides have two peaks in growth rate of body weight. Minnich (1971) found that, in the field, desert iguanas (Dipsosaurus dorsalis) of any given body length were heavier in spring than in summer. The two rapid annual increases in BW growth rate, observed in the Japanese grass snake, can be explained as follows. From the observation that SVL began to increase a few weeks later than BW in spring, it appears that some body weight is needed to increase SVL, and this may be related to the above-mentioned idea that food consumption primarily affects 
body weight rather than length. On the other hand, the rapid increase of $\mathrm{BW}$ in autumn is possibly due to the necessity of saving nutrition as preparation for hibernation. This explanation is corroborated by the fact that snakes in Group $\mathrm{C}$ continued to take food late in autumn.

Fukada (1960) reported that the Japanese grass snake exhibits a sexual dimorphism in tail ratio. However, his figure showed that young snakes $353 \mathrm{~mm}$ in total length have the same tail length in both sexes. In the present study, I found that tail ratio in the male becomes larger than in the female when the snakes reached $290 \mathrm{~mm}$ in total length. The regression equations in the present study $(\mathrm{y}=$ $0.195 \mathrm{x}+1.03$ in females and $\mathrm{y}=0.232 \mathrm{x}$ +3.99 in males, where $x=$ total length and $y=$ tail length) were similar to those demonstrated by Fukada $(1960, y=0.199 x$ +1.06 in females and $y=0.261 x-1.13$ in males).

ACKNOWLEDGments.-I wish to express my thanks to $\mathrm{H}$. Ota for his careful reading of the manuscript and for his valuable comments, and to T. Hikida for his cooperation in analyzing the data with the computer and for providing helpful comments on earlier drafts of this paper. I also thank S. Ishihara, H. Moriguchi, and R.C. Goris for literature. Several colleagues in the Kyoto University Wildlife Research Association provided kind assistance in keeping and measuring animals. Without their help this study would not have been accomplished.

\section{Literature Cited}

Acharjyo, L. N. AND CH. G. Mishra. 1980. Growth rate of Indian python, Python molurus molurus (Serpentes: Boidae) in captivity with special reference to age at first egg-laying. J. Bombay Nat. Hist. Soc. 77(2): 344-350.

Barnard, S. M., T. G. Hollinger AND T. A. RoMAINE. 1979. Growth and food consumption in the corn snake, Elaphe guttata guttata (Serpentes: Colubridae). Copeia 1974 (4): 739-741.

COOPER, J.E. AND O.F. JACKSON. eds. 1981. Diseases of the reptiles. Vol 2. Academic Press, New York. pp. 418-419.

DMI'EL, R. 1967. Studies on reproduction, growth, and feeding in the snake Spalerosophis cliffordi (Colubridae). Copeia 1967 (2): 332-346.

ForD, N.B. 1974. Growth and food consumption in the yellow rat snake, Elaphe obsoleta quadrivittata. Herpetologica. 30(1): 102-104.

FowLER, M.E. editor-in-chief. 1978. Zoo and wild animal medicine. W.B. Saunders Company, Philadelphia. $125 \mathrm{p}$.

Fukada, H. 1959. Biological studies on the snakes. VI. Growth and maturity of Natrix tigrina tigrina (Boie.). Bull. Kyoto Gakugei Univ. Ser. B 15: 25-41.

Fukada, H. 1960. Biological studies on the snakes. VII. Growth and maturity of Elaphe quadrivirgata (Boie). Bull. Kyoto Gakugei Univ. Ser. B 16: 6-21.

FuKadA, H. 1967. Biological studies on the snakes. XII. Excavation of a hibernaculum. Bull. Kyoto Gakugei Univ. Ser. B 31: 23-25.

FuKADA, H. 1972. Growth and maturity of some Japanese snakes (review). The Snake 4(2): 75-83. (in Japanese with English abstract)

GorIS, R.C. 1971. The hibernation of captive snakes. The Snake 3(1): 65-69.

HiRTH, H.F. 1966. Weight changes and mortality of three species of snakes during hibernation. Herpetologica 22(1): 8-12.

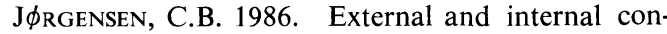
trol of patterns of feeding, growth and gonadal function in a temperate zone anuran, the toad Bufo bufo. J. Zool., Lond. (A) 210(2): 211-241.

Kamura, T. 1975. Rearing of young habu (Trimeresurus flavoviridis) in laboratory. I. Observations for three years. Report of Okinawa Prefect. Institute of Public Health (9): 127138. (in Japanese)

Kamura, T. AND K. Shimamura. 1980. Rearing of habu (Trimeresurus flavoviridis) in laboratory. II. Observations for seven years. Report of Okinawa Prefect. Institute of Public Health (14): 59-73. (in Japanese)

KLAUber, L.M. 1937. A statistical study of the rattlesnakes. IV. The growth of the rattlesnake. Occas. Pap. San Diego Soc. Nat. Hist. 3: $1-56$.

Marcus, L.C. 1981. Veterinary biology and medicine of captive amphibians and reptiles. Lea \& Febiger, Philadelphia. pp.176-178.

MinNiCH, J.E. 1971. Seasonal variation in weightlength relationships and fat body size in the desert iguana, Dipsosaurus dorsalis. Copeia 1971(2): 359-362.

Mishima, S., Y. Sawai, S. Yamasato, M. Toriba, AND K. SawaI. 1977. Studies on a natural monument, Shirohebi (albino Elaphe climacophora) on the Iwakuni in Japan. 2. Study on the captive breeding of the snakes, young Shirohebi (2). The Snake 8(2): 121-144.

Moriya, A. AND S. Higashizono. 1986. Growth and food consumption in the Mamushi, Agkistrodon blomhoffii blomhoffii (Boie), in captivity. Jpn. J. Herpetol. 11(3): 110-123.

Myer, S.J. AND A.P. Kowell. 1971. Eating patterns and body weight change of snakes when eating and when food deprived. Physiol. Behav. 6: 71-74.

Myer, S.J. AND A.P. Kowell. 1973. Effects of 
feeding schedule and food deprivation on the growth of neonatal garter snakes (Thamnophis sirtalis). J. Herpetol. 7(3): 225-229.

Naulleau, G. AND B.V.D. Brule. 1981. Feeding, growth, moult and venom production in the Russell's viper Vipera russelli in captivity. International Zoo Yearbook 21: 163-172.

Specter, P.C., J.H. Goodnight, J.P. SAll, ANd W.S. SARLE. 1985. GLM. In: SAS version 5. SAS Institute, Inc., Cary, North Carolina.

\section{要旨 飼育下におけるヤマカガシの幼蛇の成長}

森哲

ふ化直後のヤマカガシ 27 個体を 2 年 4 カ月に わたって室温下で飼育した。これらの個体を 9 個体ずつ 3 つの群に分け，それぞれ 2 日，4 日，6日毎に同量の小魚を与え，成長の違い, 及び成長の季節変動を見た。ふ化後 4 週間で, 2 日毎の群は頭胴長，体重に拈いて 4 日毎の群 より大きくなったのに対し，4 日毎の群は体重 においてのみ 6 日毎の群より大きくなった。一 pp. 433-506.

TAKENAKA, S. 1980. Growth of the Japanese grass lizard Takydromus tachydromoides in relation to reproduction. Herpetologica 36(4): 305310.

Department of Zoology, Faculty of Science, Kyoto University, KitashirakawaOiwakecho, Sakyo-ku, Kyoto, 606 JAPAN

方, 肥満度 (体重 $/$ 頭胴長 $^{3}$ ) はふ化 1 年以後. 4 日毎の群が 2 日毎の群よりも大きくなった。 体重は冬季直前と直後に急速に増加したのに対 し，頭胴長は春から秋にかけてゆっくりと增加 した。この季節変動はどの群においても同樣に 見られた。また，全長が $290 \mathrm{~mm}$ 以上になると 雄の尾率は雌のそれよりも大きくなった。

(606 京都市左京区北白川追分町 京都大学理 学部動物学教室) 